\title{
Growth response of olive cultivars to air layering
}

Fiaza Afzal ${ }^{1}$, Muhammad Adnan ${ }^{1 *}$, Inayat Ur Rahman ${ }^{1}$, Muhammad Noor $^{1}$, Ahsan Khan ${ }^{2}$, Sadia Iqbal ${ }^{3}$, Jawad Ali Shah ${ }^{1}$, Mushtaq Ahmad $\mathrm{Khan}^{1}$, Muhammad Roman ${ }^{4}$, Fazal Wahid ${ }^{1}$, Shah Nawaz ${ }^{5}$, Rainaz Perveez $^{6}$ and Fazli Subhan ${ }^{1}$

1. Department of Agriculture, University of Swabi-Pakistan

2. Department of Zoology, University of Swabi-Pakistan

3. Department of Agriculture chemistry, the University of Agriculture Peshawar-Pakistan

4. Department of Botany, University of Chitral, KPK-Pakistan

5. Department of Soil and Environmental Sciences, the University of Agriculture, Peshawar-Pakistan

6. Department of Botany, Government Girls Degree Collage, Dargai-Pakistan

*Corresponding author's email: $\underline{\text { madnanses@gmail.com }}$

Citation

Fiaza Afzal, Muhammad Adnan, Inayat Ur Rahman, Muhammad Noor, Ahsan Khan, Jawad Ali Shah, Mushtaq Ahmad Khan, Muhammad Roman, Fazal Wahid, Shah Nawaz and Rainaz Perveez. Growth response of olive cultivars to air layering. Pure and Applied Biology. Vol. 6, Issue 4, pp1403-1409.

http://dx.doi.org/10.19045/bspab.2017.600151

\begin{tabular}{llll}
\hline \hline Received: 21/08/2017 & Revised: 07/11/2017 & Accepted: 20/11/2017 & Online First: 24/11/2017
\end{tabular}

\section{Abstract}

The olive (Olea europaea saliva L.) has been little studied for its genetic improvement due to slow rate of seed germination, long juvenile phase and pre-vailing self-incompatibility. That's why this study was conducted to assess the "Response of different olive varieties to air layering" during July, 2016 at Olive Research Farm Sangbhatti, Agricultural Research Institute (ARI) Tarnab, Peshawar, Pakistan. Air-layering was done in July on five olive cultivars (pendalino, coranica, chetoui, leccino and local variety) using rendomized complete block (RCB) design having three replications. Our findings revealed significantly different results for days to rooting, number of roots plant, root length, root diameter and root weight in response to air layering. Olive cultivar pendalino took maximum days to callus formation and rooting and produced longer and denser roots, while with respect to root diameter and weight chetoui was observed best cultivar. Local verities took minimum days to root and callus appearance and established earlier compared to others. On the basis of the aforesaid results variety chetoui performed best in terms of rooting. Thus it is recommended that in area with sufficient water availability local cultivar should be grown while cultivar chetui should be grown in area with scares water availability because of its good rooting system and produce relatively good yield than others cultivars.

Keywords: Air layering; Callus formation; Olive; Root length; Root diameter

\section{Introduction}

Olive (Oleaeuropea L) is from family Oleaceae and cultivated for edible oil and fruits. Olives have not been conventionally grown in Pakistan for the edible oil production, except few areas including plain and hilly [1]. It is initiated in the eastern Mediterranean region and its practices started in Spain, Italy and $\mathrm{N}$ Africa later than in the eastern Mediterranean area [2]. Olive profitable production is found between $30^{\circ}-45^{\circ}$ north and south of equator around the world [3]. Pakistan have the same agro climatic 
condition and soil factors for olive production, due to which have the ability for the tropical, subtropical and temperate fruit trees can be grown. Olive can be grown successfully in sub-tropical mountainous region of Khyber Pakhtunkhwa, Baluchistan and northern area of Pakistan [4].

Olive is propagated by sexual (vegetative) as well as asexual (seed) methods. Propagation of olive through sexual mean is not generally recommended, for the reason that seedlings are not true to type and it will take much more time to bear fruits [5]. Asexual or Vegetative propagation methods can possibly be the most usually used commercial method of propagation in olive. Asexual propagation methods consists of cutting, budding, grafting and air-layering [6], but mostly propagation is done through air-layering because it takes comparatively less time. Air layering is usually done in the months from JuneAugust. Branches from well-developed trees, free from pests and diseases are selected for air-layering. A branch of 5$10 \mathrm{~mm}$ in diameter is selected and bark of $1 / 2-1$ inch is removed, covered with garden soil and any other rooting medium and then wrap with polythene film. When a good ball of roots has formed, the branch is then cut off below the wrapped soil after which is generally placed in larger tube or pot to become more firmly established before being set out permanently [5]. [7] Air layered one year old shoots on several dates between July-November and observed rooting percentage and establishment (in three cultivars), survival after transplanting (in two cultivars).

In air-layering shoot is not buried in soil, first a small cut is given to shoot and then sphagnum moss is wrapped through polythene around the cutting portion. Since cutter portion is exposed not buried in soil, you may see root development, when roots develop detach shoot from parent plant and plant it [8].

The olive is major agricultural significance of Mediterranean area as the source of olive oil and it is one of the three core constituents in Mediterranean cuisine. Olive is a rich source of vitamin $E$ and contains a large amount of sodium. Olive contains $75 \%$ water $4 \%$ carbohydrates and $1 \%$ protein [9]. Black olives are a good source of iron which is important for the transport of oxygen in red blood cell [10]. It also contain copper which is essential mineral is often lacking in the typical western diet. Numerous varieties have been tried in the state with cold hardiness being the key selection factor. Not all varieties perform the same at all locations. It may be that one variety does well for your neighbour, but just across the street at your farm it does horribly. Differential varietal performance has been noted among adjacent or-chards. Therefore this study was initiated to find out the response of different olive varieties to air layering at the agro climatic conditions of Peshawar region.

\section{Materials and methods}

An experiment was executed at Olive Research Farm Sang Bhatti, to study the response of different olive varieties to air layering. Five different varieties Pendilino, Leccino, Karonika, Chetuei and control (local verity) were evaluated in field experiment using randomized complete block (RCB) design with three replication. Sixteen air-layers techniques were practiced in each verity of olive plant keeping 80 (16 x 5) plants per replication. In order to initiate rooting in olive cultivar chetuei, branches a circular strip of bark having $3 \mathrm{~cm}$ size was completely removed just below the buds from one year old shoots. The branches used for air-layering had $1.5 \mathrm{~m}$ length and pencil size thickness. Seven years old plants have been selected for the experiment. A heavy mass of prepared media was tightly wrapped around layered branches readily after the removal of bark to reduce moisture evaporation from the opened portion. The media were covered with polyethylene sheets to make sure that the media remain intact. After the air-layering all the plants were frequently 
irrigated. Data were collected after 20 days. The branches which have effective development of roots in media were cut off carefully below the layered potion from parent plants and data were recorded for different parameters. All other cultural parameters were kept uniform for all the treatments during this way of experiment.

\section{Data collection}

Total number of days to callus development was counted from the date of air-layering to the development of callus. Total number of days to root appearance was calculated from the date of layering to the appearance of roots. To record the number of roots per air-layered shoot plant were cut and the media attached with roots was washed away with water and was removed completely. Subsequent to cleaning, the length of roots was measured in centimeters with the help of measuring tape from the point of emergence to the apex of most noteworthy root. The diameter of roots was measured with the help of vernier caliper in millimeter subsequent to cleaning the roots from media with water. Weight of the roots per air-layered shoot was measured in grams by digital balance after proper washing and processing.

\section{Statistical analysis}

The noted data was analysed statistically by using statistical software GenState 8.1 [11]. Upon least significance difference (LSD) test have been used for means comparisons to find out the significant components of the treatment means [12].

\section{Results and discussion \\ Days to callus formation}

Callus is a mass of immature plant cells which can differentiate into mature tissues, depending upon the relative concentrations of plant growth hormones present. Callus can develop form explants in laboratory tissue culture experiments but also occurs naturally at the end of cut or wounded surfaces of shoots and roots. Callus development was affectively influenced by the growth media in different olive cultivar as presented in figure 1 . With respect to the variety variations, we found that the callus induction frequencies are comparatively much higher in variety Pandilno and coranica which took statistically similar time for callus formation while the remaining cultivar took relatively less time.

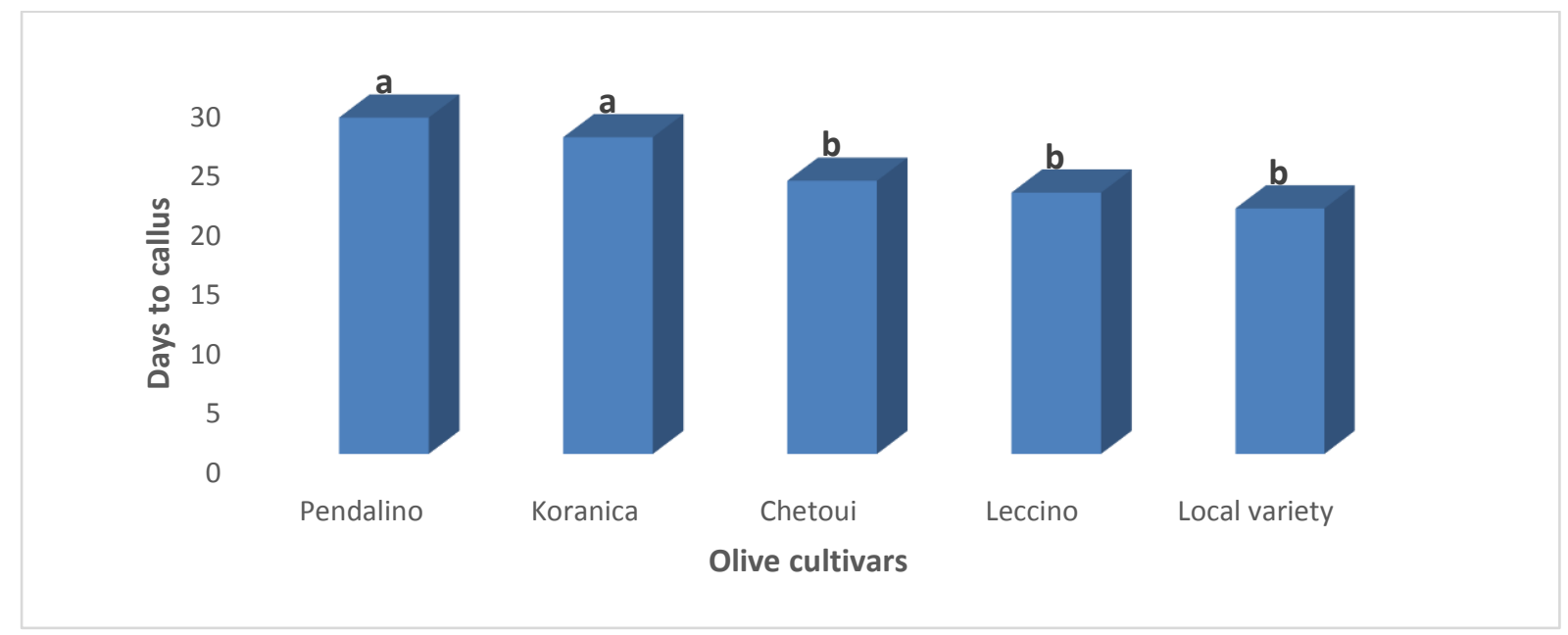

Figure 1. Days to callus of different variety of olive. Mean with different letters are significantly different (5\% level of significance), $C V=7.39$ and $L S D=3.3$

These results are in line to the [8], who stated that cultivar may behave different with respect to regeneration due to their genetic and physiological characteristics.

\section{Days to rooting}

Days to rooting were significantly influenced by various types of olive varieties as presented in figure 2 . The 
highest days to rooting were recorded in cultivar (Pandilino) which was 62 days, while the lowest were recorded for local verity. Chetoui took such a time to rooting which was statistically similar to cultivar Leccino and Coranica. It shows that the best result of days to emergence were recorder in local variety. This variation in the sprouting is due to the fact that cultivar sprouted earlier depending upon length of cuttings and nature as reported by [13] who also recorded different results in cultivated and wild olive cuttings.

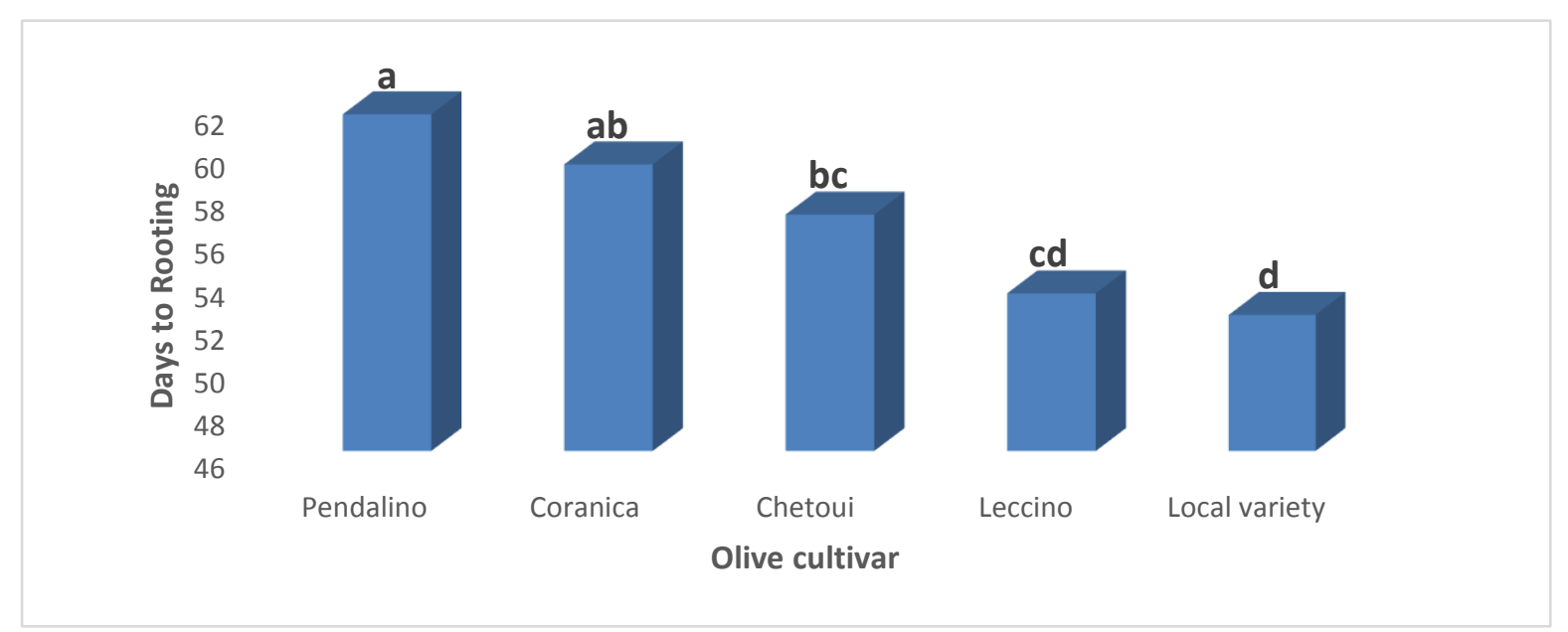

Figure 2. Days to rooting for different varieties of olive. Mean with different letters are significantly different (5\% level of significance), $C V=4.05$ and $L S D=4.32$

\section{Number of roots plant ${ }^{-1}$}

The number of roots per plant was significantly affected in response to different olive cultivar as presented in figure 3. Upon analysis best result was obtained in pendalino cultivar which was alike to coranica and higher than chetouie, while the lowest number of roots per plant was recorded in local variety (3.66 roots per plant) which was similar to leccino. These results similar to [8] who recorded up to 8.30 roots plant- ${ }^{1}$. Differences in verities with respect to rooting ability are because of the adjustment of this cultivar to our agro-atmospheric conditions.

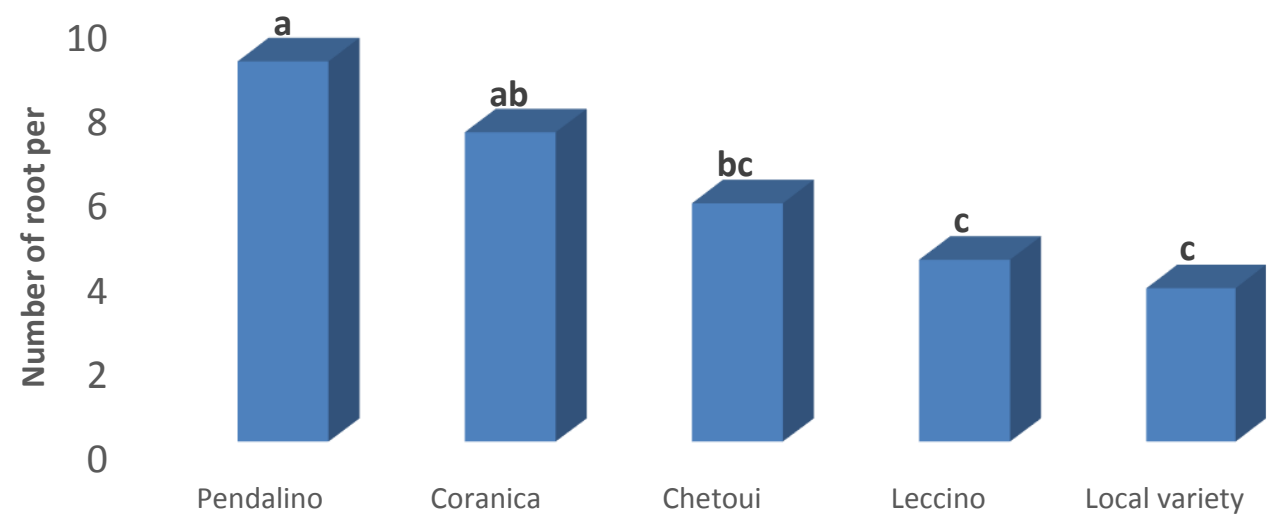

Olive cultivars

Figure 3. Number of roots per plant for different varieties of olive. Mean with different letters are significantly different (5\% level of significance), $C V=38.85$ and $L S D=4.32$ 
Root length $(\mathrm{cm})$

Root length was statistically influenced by different types of growing varieties (Figure 4). Analysis of variance showed longer roots for pendalino which was statistically equal to corannica and chetoui while the lowest root length was recorded in local control which was $2.1 \mathrm{~mm}$. Root length grows down and is very effective in engrossing moisture and nutrient for plant growth and development. The results are not in line with [8] who found maximum root length 7.01 in a verity adjustable to the growing conditions. Thus it may be found that root length of a cultivar may vary depending upon their resistance to moisture stress and adoptability to the agro-climatic conditions.

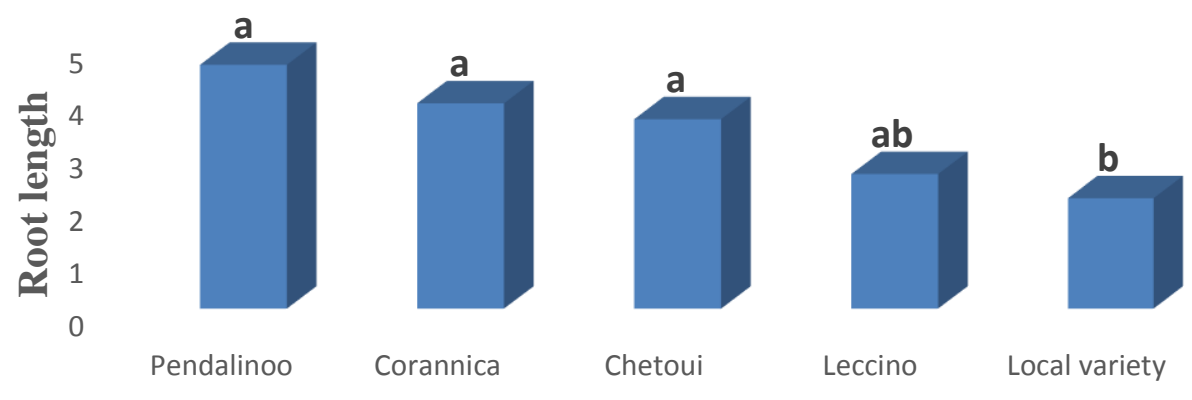

Olive cultivar

Figure 4. Root length and different varieties of olive. Mean with different letters are significantly different ( $5 \%$ level of significance), $C V=13.75$ and $L S D=0.87$

\section{Root diameter ( $\mathrm{mm})$}

The results regarding root diameter in response to different cultivar is presented in figure 5. Significant changes were observed in different olive cultivar for root diameter. . Thickest root $(1.39 \mathrm{~mm})$ was recorded in treatment Chetoui while the thinner root was observed in treatment Pendalino which is $(1.15 \mathrm{~mm})$. These results show that for the good root development the best variety is Chetoui. The narrow root diameter find may be possibly due to a high rainfall and low temperature because of harsh and cool weather which affect the root diameter [13].

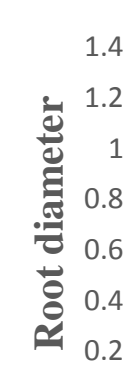

0

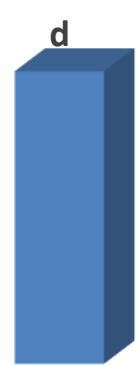

Pendalino

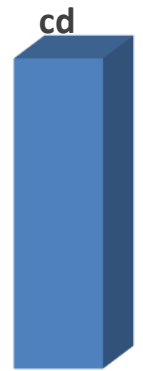

Coranica

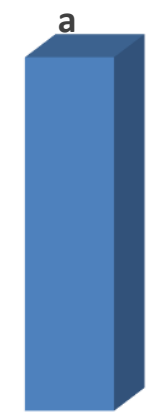

Chetioui

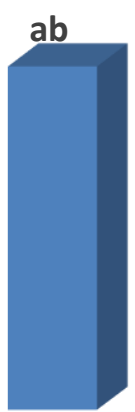

Leccino

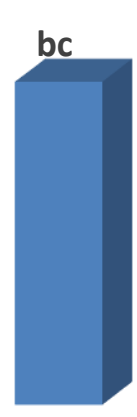

Local variety

Olive cultivar

Figure 5. Root diameter $(\mathrm{mm})$ of different varieties of olive. Mean with different letters are significantly different (5\% level of significance) $C V=4.18$ and $L S D=0.10$ 


\section{Root weight (g)}

The data for the root weight has shown in figure 6. ANOVA showed high significant differences in root weight for different olive cultivar. The heaver roots $(0.67 \mathrm{~g})$ were recorded in chetoui which were statistically identical to leccino and local cultivar while the lighter roots were found for pendalino $(0.27 \mathrm{~g})$. It shows that the local variety performed better than pendalino and coranica which support the findings of [14] as it have more root length and diameter which ultimately leads to heaver roots.
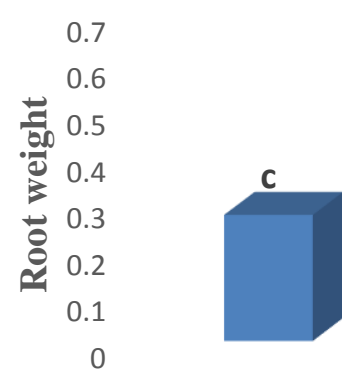

pendalino

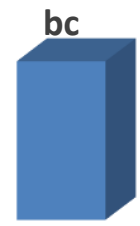

coranica

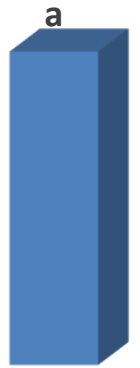

chetoui

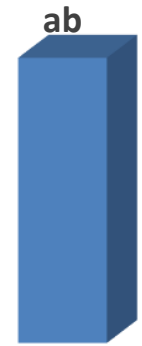

leccino

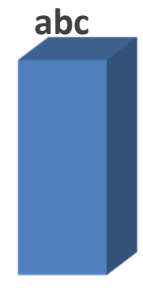

local varriety

Olive cultivars

Figure 6. Root weight and different varieties of olive. Mean with different letters are significantly different (5\% level of significance), $\mathrm{CV}=37.27$ and $\mathrm{LSD}=\mathbf{0 . 3 2}$

\section{Conclusions and recommendations}

It is concluded from the experiment that different olive cultivars responded significantly to air layering. Pendalino took maximum days to callus formation and rooting and produced longer and denser roots, while chetoui was observed best cultivar with respect to root diameter and weight. Local verities established earlier compared to others but had a weak rooting system. Thus it is recommended that in area with sufficient water availability local cultivar should be grown while cultivar Chetui could be grown in area with scares water availability.

\section{Authors' contributions}

Conceived and designed the experiments: $F$ Afzal, M Adnan \& IU Rehman, Performed the experiments:, M Noor, A Khan, JA Shah \& MA Khan, Analyzed the data:, M Roman \& F Wahid, Contributed materials/ analysis/ tools:, S Nawaz, R Perveez \& F Subhan, Wrote the paper: F Afzal, M Adnan \& IU Rehman.

\section{References}

1. Wilson P (1920). Manual of tropical and subtropical fruits. MacMillan publishing Co., Inc. New York pp. 321323.

2. Seyhan O \& Gezerel O (2005). The Effects of the different doses of IBA (Indol butyric acid) on the rooting performances in the reproduction of "Gemlik" and "Domat" olive trees by using the green twig procedure in the ecology of cukurova region. Central European J Agric 6(4): 481-484.

3. Awan AA, Ullah E, Abbas SJ, Khan O \& Masroor S (2012). Growth response of various olive cultivars to different cutting lengths. Pak J Agri Sci 49(3): 315-318.

4. Wilson P (1920). Manual of tropical and subtropical fruits.MacMillan publishing Co., Inc. New York.

5. Kanwar JS \& Kahlon GS (1986). Propagation studies in litchi. J Res Punjab Agric Univ 23(1): 33-39. 
6. Baloch A (1994). Hort. Phases of plant growth. National Book Foundation Islamabad. pp. 633.

7. Kadman A (1983). Propagation of subtropical fruit trees by air layering. M.Sc (Hons) Thesis 1997, Department of Horticulture, NWFP Agricultural University Peshawar.

8. Rugini, E (1984). In vitro propagation of some olive (Olea europaea sativa L.) cultivars with different root-ability, and medium development using analytical data from developing shoots and embryos. Scientia Horticulturae 24(2): 123-134.

9. Visioli, F, Romani A, Mulinacci N, Zarini S, Conte D, Vincieri FF, \& Galli C (1999). Antioxidant and other biological activities of olive mill waste waters. $J$ of Agricultural and Food Chemistry 47(8): 3397-3401.

10. Manna, C, D'Angelo S, Migliardi, V, Loffredi E, Mazzoni, O, Morrica P \& Zappia, V (2002). Protective effect of the phenolic fraction from virgin olive oils against oxidative stress in human cells. Journal of agricultural and food chemistry 50(22): 6521-6526.

11. Gen Stat (2005). GenState 8th edition. Release 8.1. VSN International, Oxford, UK.

12. Gomez KA \& Gomez AA (1980). Statistical procedure for Agricultural Research An international Rice Research Institute Book. John Wiley and sons, 2nd edition. p.190

13. Shakir USM, Awan AA \& Nasar MS (2004). Performance of cultivated and wild olive cuttings as affected by different length and diameter. Sarhad $\boldsymbol{J}$ Agric 20(3): 367-372

14. Eman AA, Abd El-moneim MMM, Abd El-Migeed $\mathrm{O} \&$ Ismail MM (2007). GA3 and Zink sprays for improving yield and fruit quality of Washington Navel orange trees grown under sandy soil conditions. Res $J$ Agric Biol Sci 3(5): 498-503. 